\title{
ERRATUM
}

\section{Erratum to: New Patient-Oriented Tools for Assessing Atrophic Acne Scarring}

\author{
Alison Layton $\cdot$ Brigitte Dréno $\cdot$ Andrew Y. Finlay $\cdot$ Diane Thiboutot $\cdot$ \\ Sewon Kang $\cdot$ Vicente Torres Lozada $\cdot$ Valerie Bourdès · \\ Vincenzo Bettoli $\cdot$ Laurent Petit $\cdot$ Jerry Tan
}

Published online: March 23, 2016

(C) The Author(s) 2016. This article is published with open access at Springerlink.com

Erratum to: Dermatol Ther (Heidelb)

DOI 10.1007/s13555-016-0098-5

The Acknowledgments section incorrectly states that "The authors wish to thank Valerie Sanders, from Sanders Medical Writing, for assistance in preparing this article. Support for this assistance was provided by Galderma International. Sponsorship for this study and article processing charges was funded by Galderma International."

This section should read as follows:

The online version of the original article can be found under doi:10.1007/s13555-016-0098-5.

\section{A. Layton}

Department of Dermatology, Harrogate District

Hospital, Harrogate, UK

B. Dréno

Department of Dermatology, Hotel Dieu, Nantes, France

A. Y. Finlay

Department of Dermatology, Cardiff University

School of Medicine, Cardiff, UK

D. Thiboutot

Department of Dermatology, Hershey University, Hershey, PA, USA

S. Kang

Department of Dermatology, Johns Hopkins School

of Medicine, Baltimore, MA, USA
"The authors wish to thank Valerie Sanders, from Sanders Medical Writing, for assistance in preparing this article. Support for this assistance was provided by Galderma International. Article processing charges were funded by Galderma International. Sponsorship for the study was funded by Galderma R \& D."

\footnotetext{
V. T. Lozada

Department of Dermatology, Juarez Hospital, Mexico City, Mexico

V. Bourdès $(\varangle) \cdot$ L. Petit

Galderma R \& D, Sophia Antipolis, France

e-mail: valerie.bourdes@galderma.com

V. Bettoli

Department of Dermatology, University of Ferrara, Ferrara, Italy

J. Tan

Department of Dermatology, University of Western Ontario, Windsor, Canada
} 
Open Access. This article is distributed under the terms of the Creative Commons AttributionNonCommercial 4.0 International License (http://creativecommons.org/licenses/by-nc/4. $0 /$ ), which permits any noncommercial use, distribution, and reproduction in any medium, provided you give appropriate credit to the original author(s) and the source, provide a link to the Creative Commons license, and indicate if changes were made. 